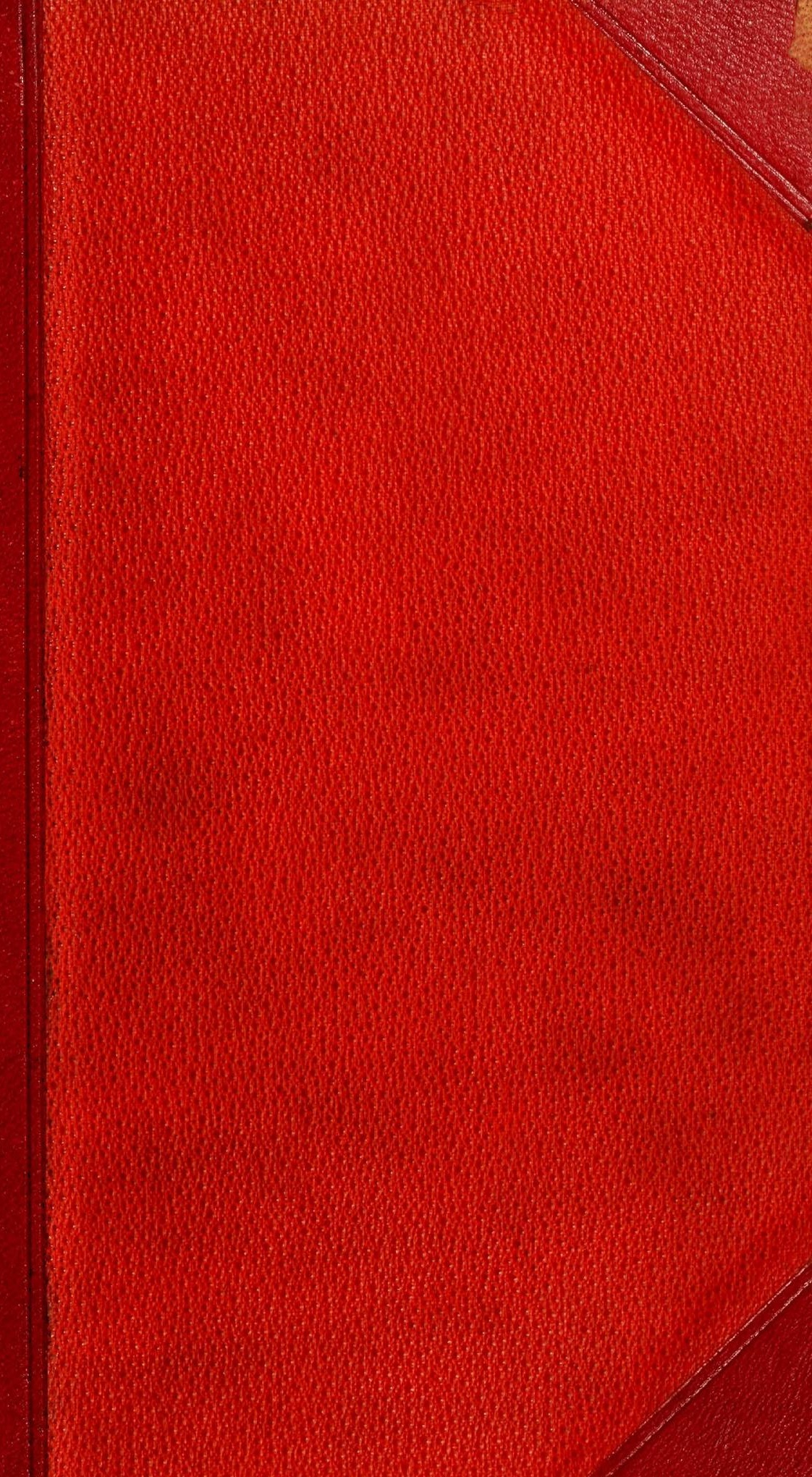




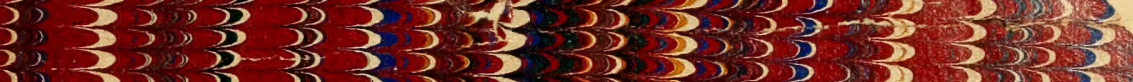

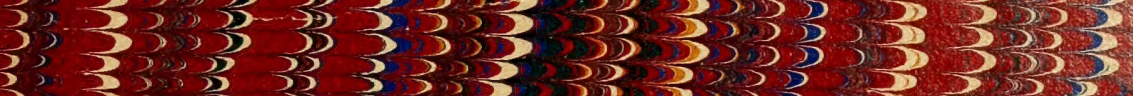

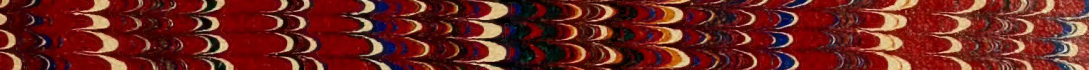

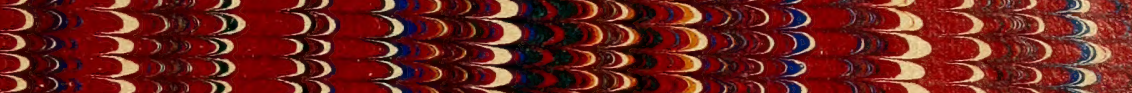

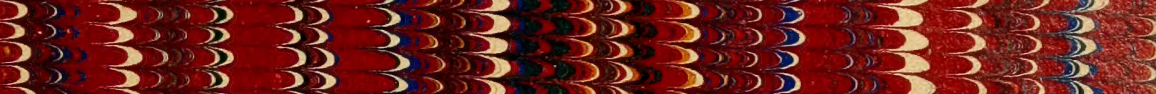

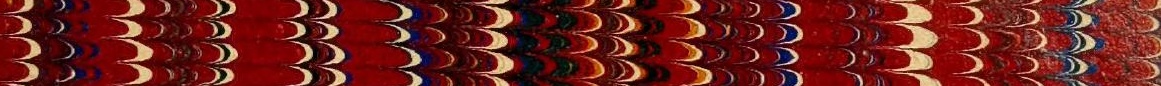

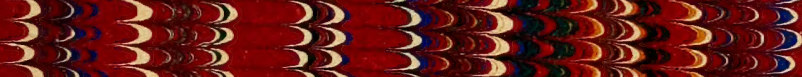

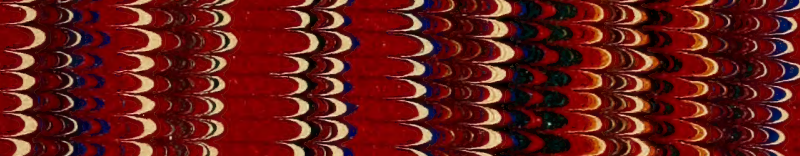

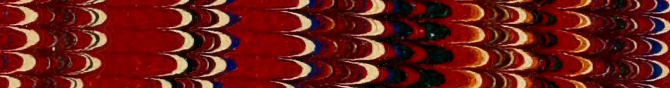

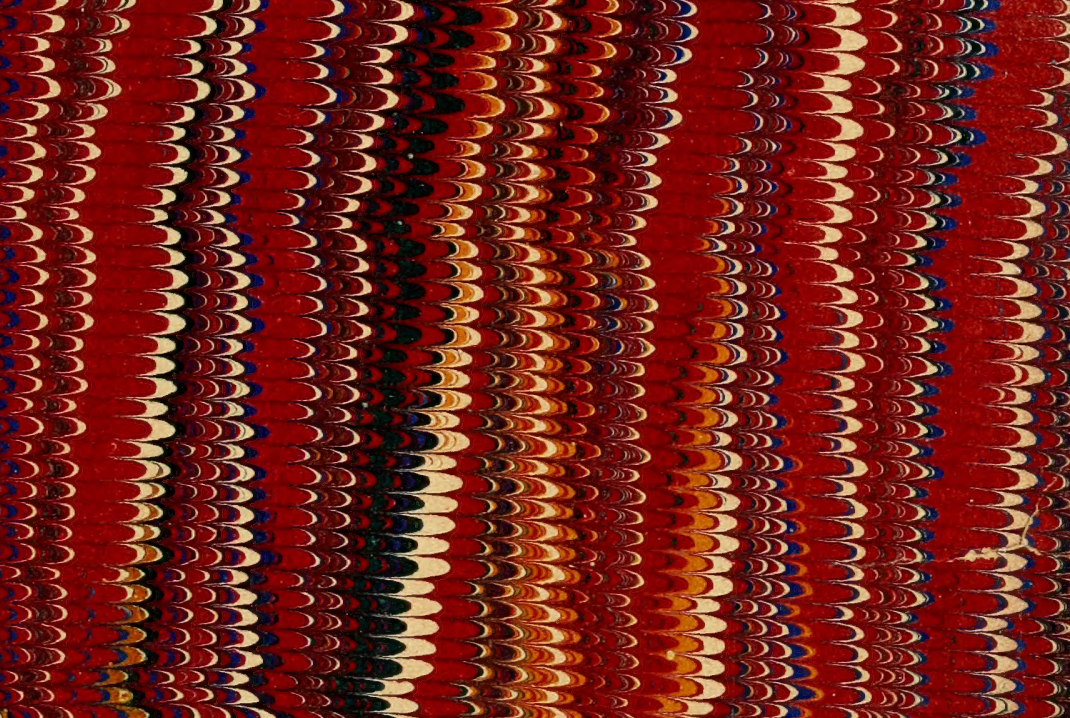

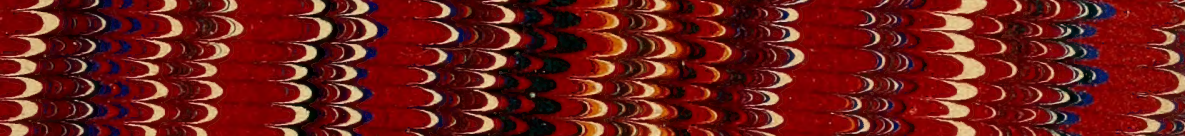

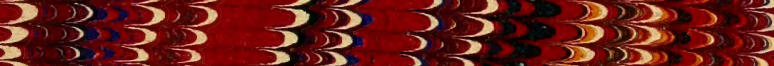

(1)

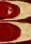

3

, $)$

3

$3>3,33$

33332335

$333,323,3$

33335353

$3333 \rightarrow 333$

$33,3,25333$

33,333

333333

33320333

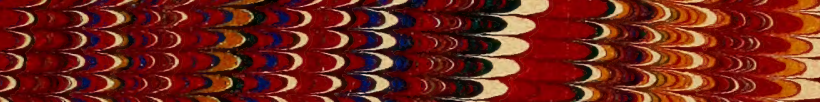

$i_{i} \sum_{3}^{3}$

3 S 325

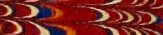

3

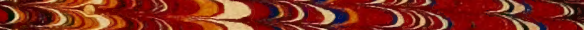

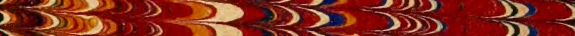

(D) 353535

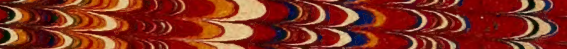

3.500535353535

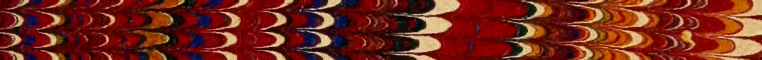

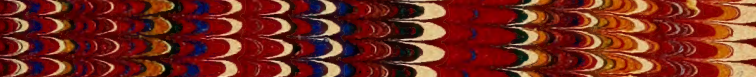

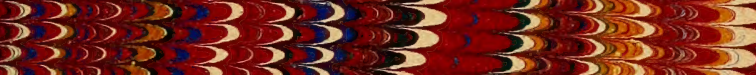

3,3353535

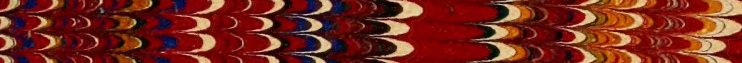

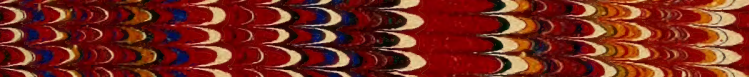

$33, \cdots, 3,3\}, \frac{3}{3}, \frac{3}{3}, \frac{3}{3}, \frac{3}{3}$

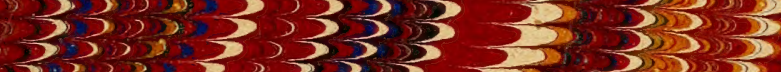

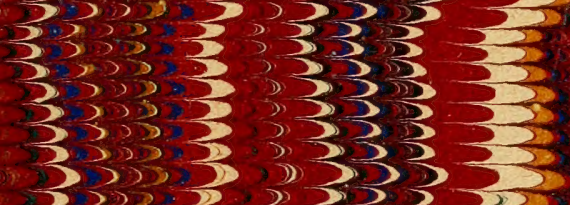

$3>0,3,35353$

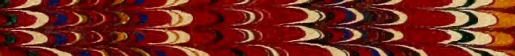

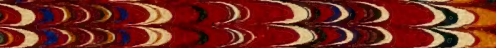

5.

( ) $\rightarrow$

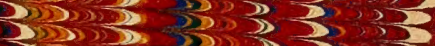

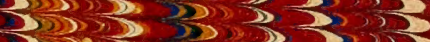

3.095353

S. $35,35.5$

3 3 $3,33,3$

Sis $35, \frac{3}{3}, 3,3$

Sis $35,33,3$

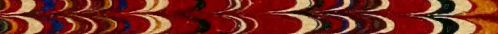

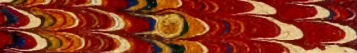




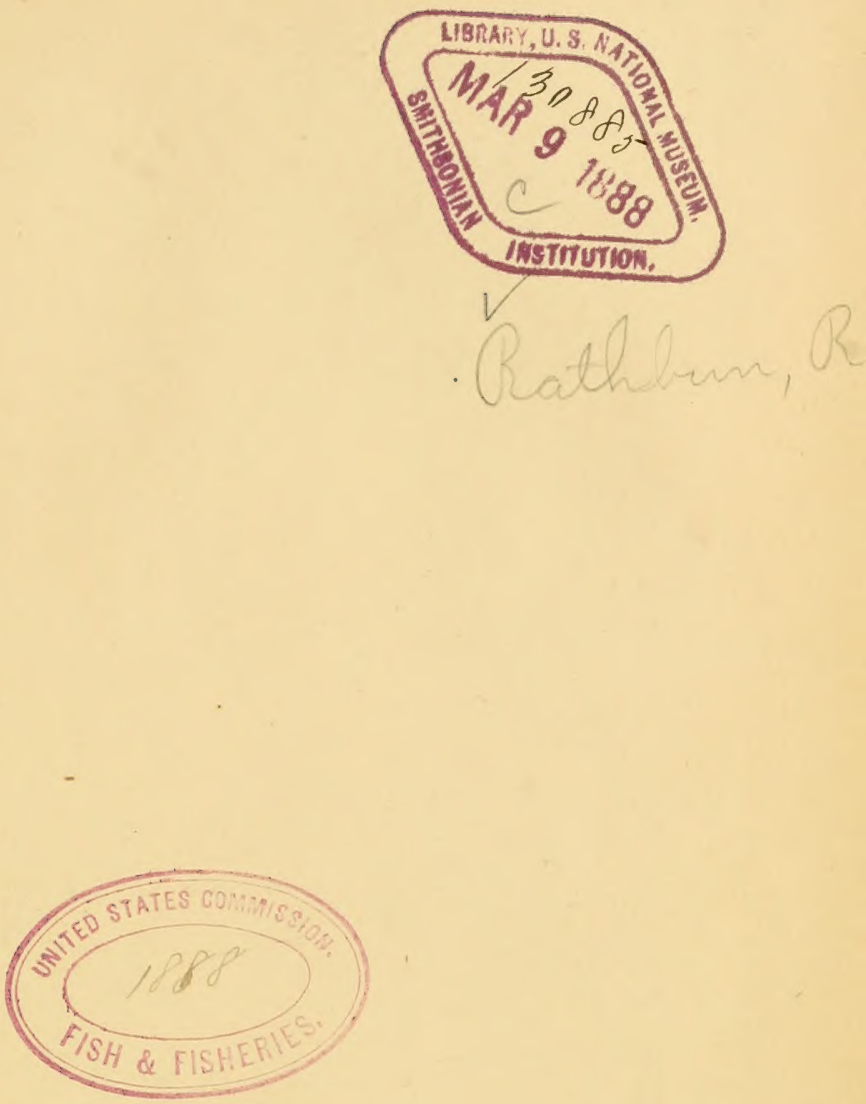



[From the Transactions of the Connecticut Academy of Arts and Sciences, VoL. V, 1879.]

\title{
A LIST OF THE
}

\section{BRAZILIAN ECHINODERMS,}

WITH NOTES ON THEIR DISTRIBUTION, ETC.

\author{
BY RICHARD RATHBUN,
}

Assistant on the United States Fish Commission. 



\section{A List of the Brazilian Eiminoderns, with Notes on theip Distribution, etc. By Richard Rathbun.}

'THe following list comprises all the species of Echinoderms collected or observed on the Brazilian Coast, by Mr. John (? Brammer, the anthor, and other members of the Geological C'ommission of Brazil, luring the years $1875-75$; together with the species hitherto recorded from that region, in the principal works treating of this class of animals.

In accordance with the instructions of the late Prof. (h. Fred. IIart, as chief of the Brazilian Survey, collections of marine animals were male at all the sea-const localities visited by the assistants of the survey, in the course of their geological explorations. The intention was to procure material from as many points as possible, to serve for the study of the geographical distribution of the several species. But the limited time available for zoological work usually rendered it impossible to collect other than the larger and commoner species, the majority of which, at least in the class of Echinolerms, had already been noticed by other travelers, as occurring on the Brazilian coast. Comparatively few additions were therefore made to the previously known Echinoderm-fauma of Brazil, only a single species, a Leptasterias, being with certainty new to science. One important result of these researches, however, was the more careful determination of the range and exact halitats of many of the species, and this, together with the fact that no complete list of the Brazilian Echinoderms has yet been published, has been deemed at sufficient reason for the preparation of the present list.

Except in a few instances, lists of synonymy have been omitted; the authority is always given for the occurrence of the species at the localities recorded-in the cases of the Geological Commission and the Hartt Expeditions it is the name of the collector, otherwise generally the publisher. Mr. Alex. Agassiz's "Revision of the Echini" is taken as the sole authority for all the localities given in the list of that group, excepting where the species were also collecterl on the private expeditions of Prof. IIartt, or ly the Geological Commission. The other authorities userl throughout the paper will be understood by reference to the list of hibliography which precentes

Trans. Conn. ACad, Vot. V. 
the lists of species. I an to be held responsible only for the identifieation of the species collected by the (reological Commission; beyond this the work is entirely a compilation. To renter the list more complete and serviceable, there has been arded the extraBrazilian range of all species not confined to that coast: where a species is widely distributed, the regions inhabited by it are indicated only in a general way; where it has been foumd at only one or a few localities, these are defined.

In the preparation of this paper, I have been placed miner many obligations to Prof. A. E. Verrill, for the use of viluable specimens and hooks. and for much aid and artrice, enabling me to better perfect my work than I could otherwise have done. 'T'o Mr. Theo. Lyman I am indebted, for the identification of sereral of the more critical Ophinrans, and for valuable suggestions in making up the list of species of that group.

The principal publications that have furnished materials for this paper, are as follows, arranged alphabetically, according to the anthors:

Agassiz, Alexander. Rerision of the Fohini. Illustrated ('atalogue of the Museum of Comparative Zoölogy at Harvard College, No. VII, 1872-74.

(trar, Joln F. Synopsis of the Species of Startish in the Britisl! Museum. London. 1866.

Ljungman, Axel Vilh. Om nagra nya arter af Ophiurider. (Efversigt af Kongl.

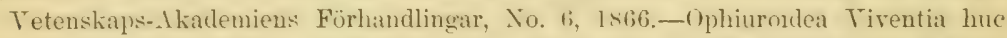
usque coguita. (Effvers. af K. Tet.-Akad. Förln.. No. 9, 1s66._Förteckning öfver uti Testindien af Dr. A. ( tiska Oceanen samlade Ophiurider. Effrers. af K. Vet.-Akad. Förh., no. 6, 1871.

Lötker. Chr. Fr. Additamenta ad Historiam Ophiuridarum, Part II, 1859. - Fortsatte kritiske og heskrivende Bidragr til Küundskah om söstjernerne (.lsteriderne). Videnskahelige Meddelelser fra den naturhistoriske Forening i Kjöhenharn, Arr. 15-19, 1871.

Lyman, Theodore. Ophiuridie and Astrophrytidie. Illustrated 'atal. of the Museum of Comparative Zoologrs, No. I, 1865.- Supplement to the Ophiuridit and Astrophytidte. Illust. Catal., No. YI, 1871.-Zö̈logical Results of the Hassler Expedition. Part II. Ophiuridæ and Astrophytidæ. Illust. Catal., No. VIII, 1875.

Müller (J.) and Troschel (F. H.) System der Asteriden, 1842.

Perrier. Edmond. Rérision de la Collection de Stellérides du Muséum d'Histoire Naturelle de Paris. Archives de Zoologie Expérimentale et Générale, t. ir, Nos. 2 and 3,1875, t. $\nabla$, Nos. 1,2 and $3,1876$.

Pourtales, L. F. de. Reports on the Results of Dredging, under the Supervision of Alexander Igassiz, in the (tulf of Mexico, hy the United states Coast Survey Steamer "Blake." (Crinoids). Bulletin of the Museum of ('omparative Zoülogs. rol. v, No. 9. 1878.

Selenka. Emil. Beiträge zur Anatomie und Systematik der Holothurien. Zeitschrift für Wissenschaftliche Zoologie, Leipzig. Vol. xvii, 1867. 
Verrill, A. E. Comparison of the Tropical Faunze of the East and West Coasts of America. Transactions of the Connecticut Academy of Arts and Scicnces, vol. i, part II, 1867.-Notice of the Corals and Echinoderms collected by Prof. C. F. Hartt, at the Abrolhos Reefs, Province of Bahia, Brazil, 1867. Trans. Conn. Acad., vol, i, part II, 1868.

\section{HOLOTHURIOIDEA.}

Chirodota rotiferum Stimpson.

Amer. Jour. Sci., xxix, p. 134, 1860 ; Verrill, Trans. Conn. Acad., i, p. 37], 1868 ; Selenka, Zeitschr. für Wiss. Zoöl., 1867, p. 367 (rotifera).

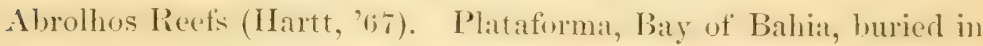
the sandy mud of tirle probs (Rathlum). Florida (Pourtales).

\section{Thyone (Sclerodactyla) Braziliensis Verrill.}

Trans. Conn. Acad., i, p. $370,1868$.

Abrolhos Reef's, miler deal consts, in the shallow tide pools and holes in the reefs (IIartt, " 65 . . Plataforma, Bay of Bahia, burierl in the mud or impure sand, filling the pools and crevices of the rocky shores (Rathbun).

\section{Thyonella, sp.}

Plataforma, Bahia (Rathlun), associated with Thyone Broziliensis.

This species of Thyonellu resembles very closely in external appearance and characters T. gemmutu Verr., * of the Southern coast of the United States, with which it might readily be united, except for the very different nature of its skin-plates. These are mostly of one kind, corresponding nearly with the larger, elongate plates of $T$. gemmatr. They are large and flattenerl, and irregularly fusiform, oblong or even triangular in mulline, with cenerally two, sometimes more, rows of larege openings. At times the openinges are irregularly scattered and of smallex size. In ardition there are more rarely slender, curved plates, with two or three perforations at each end and in the middle, or with a row of perforations.

\section{Holothuria, Sp.}

Plataforma, Balia (Rathlun), associated with Thyone Brerailiensis.

I specinen of this sprecies, in alcohol, but not much contracted, measures in length, albout 1.25m, greatest diameter, about $24^{\text {mm }}$. The

* Thyonella gemmata Verr., Amer. Jour. Sci. and Arts, III, vol. iii, p. 437, 1872.

Colochirus gemmatus Pourtalès, Proc. Amer. Ass. Adv. Sei., 1851, p. 11.

Thyonidinm yfmmotum Selenka. Zeitschrift für Tisseuschaftl. Zoül. vol. xvii. p. $345,1867$. 
skin is nearly smooth, of a brownish yellow color, and with two rows of large purplish brown spots along the dorsal sicle, and many smaller, darker spots scattered promiscuously, but most numerous on the lateral and dorsal surfaces. The skin is further covered with a net-work of fine reticulations of slight purplish color, giving it a tessellated appearance. A narrow line of the same color extends through the middle of the interambulacral spaces.

The ambulacral zones are of sub-equal width, and about two to three times as broad as the intervening spaces. The suckers are moderately abundant, slightly more numerous in the median ventral than in the other zones, but without regular arrangement, except toward the posterior extremity, where there are two rows to each zone; near the middle of the body, about four to five range across each zone. Aromol the anus there are five clusters, each of five to eight, more or less pointed papillæ.

The plates of the skin (with suckers) are very numerous, and of several very distinct kinds. The commonest kind is the smallest; minute, flattened, regularly oblong-elliptical in outline, with six small, elongate perforations, arranged in two rows. Four other kinds are common: (1.) A larger, heavier plate, with the margin forming four strong lobes, to each of which corresponds a large, circular perforation, each lobe in turn being usually diviled into two or three smaller lobes, bearing a large romited tuberele; two or three similar tubercles occur between the perforations. This plate may be much enlarged, the number of perforations increasing in proportion. A table-shaped plate, smaller than the last, and composed of a narrow, upper rim of a squarish outline--a square, with slightly curved sides and rounded corners-pierced at each comer by an oval hole, or seldom with a complete circle of perforations; and four legs, which begin just within the corner perforations, and bend strongly inward for one-half their length, to where they are banded together; below this they are straight, and closely joined at the base, leaving only a small central perforation, surromeder by ten to twelve pointed, divergent tubercles. (3.) A slender, flattenerl, elongated plate, bulging strongly outward on both sides at the center, and tapering slightly to the ends, which are also enlarged and rounded; on each side of the center there is an elongated perforation, and the rounded ends have one to three small holes. This plate is sometimes broadened and bears a row of perforations along one-half or all of one side. (4.) A rather small cage or basket-shaped plate, of nearly globular form, coming probably from the suckers. 


\section{ECHINOIDEA.}

Cidaris tribuloides (Lam.) Blainv.

Dict. S. Nat., p. 200,1830 ; A. Agassiz, Illust. Cat. Mus. Comp. Zoölogy, No. VII, p. $99,1872$.

Cidaris annulata A. Agass., Bull. Mus. Comp. Zool., p. 17, 1863.

Fernamdo de Noronba, very abmulant (Brammer). Bay of Babia, a few fragments dredged in about fonr fithoms (Rathbun). Rio de Janeiro (Mus. Copenhagen). \&. Carolina-Florida; West Indies; Gulf of Mexico; Aspinwall; Cape Verde Isls. (A. Ag.).

Arbacia pustulosa (Leske) Gray.

Proc. Zool. Soc. Londou, April, 1835; A. Agass., Illust. Cat., No. VII, p. 92, 1872.

Armaçăo and Ilhas de Mariceis, Pror, of Rio de Janeiro (IIartt, Thayer Exp.). Rio de .Janeiro, common abont entrance to Bay, etc. (Agassiz, Thayer Exp.; Rathbun). Desterro, Prov, of Santa Catharina (F. Müller). Izores; Matleira; Cape Verde Isls.; west coast of Africa; Mediterranean (A. Ag.).

\section{Diadema setosum Gray.}

Ann. Phil., p. 4, 1825 (setosa); A. Agass., Illust. Cat., No. VII, p. 103, 1872.

Fermando de Noromhat, abumlant (Bramer). The distribution of this species is nearly world-wide. West Indies; Gulf of Itexico; Carribbean Sea; Itlantic, Pacific and Indian oceans; mostly confined within the tropies (A. Ag.).

\section{Echinometra subangularis (Leske) Desml.}

Syn., p. 266, 1837; A. Agass., Illust. Cat., No. VII, p. 116, 1872.

Echinometra Hichelini Desor, Catal. Rais., 1846; A. Agass., Bull. Mus. Comp. Zoology, p. 21, 1863; Velrill, Trans. Conn. Acad., i, p. 369, 1868.

Fernando de Norouha (Bramer). Peruambuco, boring into the santstone reef, etc. (Geol. ('omm.). Island of Santo Aleixo, Pernambuco, boring into trap reck (Bramner). Bay of Bahia, rery abundant, boring into coral reef, conglomerate, gneiss, ete. (Geol. Comm.) Porto Seguro; Victoria; ( Copelami, Thayer Exy.). Abrolhos Islauds (IIartt, 1867; Rathbun). Rio te Jameiro (Agassiz; (reol. Comm.). Desterro (F. Müller).

This species has been found on nearly all the rocky shores of the coast of Brazil, from Pernambueo to sianta Catharina, and probably also ranges to the north and south of these points. It has the power 
of boring into many difterent kinds of rocks, which are sometimes so completely ridilled with its holes, that they yield readily to the force of the waves. It is edible, and comtributes to the support of the poor fishermen of the coast, where it occurs (Hartt).

s. Carolina-Florida; Wrest Indies; Aspinmall; Cumana; Bermudas; Cape Verde Isles (A. Ag.).

\section{Strongylocentrotus Gaimardi (Ilainv.) 1. Agaswiz.}

Illust. Cat. Mus. Comp. Zool., No. VII, p. 163, 1872.

Brazil (Jardin de Plantes; IIatt and Copelant, Thayer Exp.). Bahia; Rio de. Janeiro (Mus. (openhagen). Desterro (F. Müller).

\section{Toxopneustes variegatus (Lam.) A. Agass.}

Illust. Cat., No. VII, p. 168, 1872.

Lytechinus variegatus A. Agassiz, Bull. Mus. Comp. Zool., p. 24, 1863; Verrill, Trans. Conn. Acad., i, p. 369, 1868.

Fermando de Noronha (Bramer). Permambuco (Geol. Comm.). Bay of Bahia, common (IIartt, '(it); Rathbun). Porto Seguro; Vietoria; Armaçăo; ('alpe Frio (IIartt, Thayer Exp.). Alcobaça, Bahia (Max, zu Nen Wied). Bay of Rio de Jameiro (Agassiz; Rathbun). N. Carolina-Florina; W. Indies; Gulf of Mexico; Bermudas (A. Ag.). This species is sair not to be edible (Neu Wied).

\section{Hipponoë esculenta (Leske) A. Agass.}

Illust: Cat., No. VII, p. 135, 1872.

Tripneustes ventricosus Agassiz, Int. Mon. Scut., 1841.

Fernando de Noronhat, abumblant and of larege size; Rio Formoso, common and large (Branner). Florida; West Indies; Yucatan; Cumana; Surinam; Bermudas (A. Ag.).

Clypeaster subdepressus (Gray) Agass.

Prod., p. 187, 1836; A. Agass., Illust. Cat., No. VII, p. 101, 1872.

Baly of Bahia, not uncommon on sandy bottoms, and often attaining a large size (Rathbun). Brazil (Castelneau). S. Carolina-Florida ; Vest Indies; west coast of Africa ( $\mathrm{A} . \mathrm{Ag}$.).

Mellita sexforis (Lamk.) A. Agass.

Illust. Cat., No. VII, p. 141, 1872.

Pernambuco (O. A. Derby, 1870, in Mus. Yale Coll.). Bay of Rio de Janeiro, very abuntant near Fort Villegagnon, on sandy bottom 
(Prof. Emil Selenka, 187ъ). S. Carolina-Florida; West Indies; Mexico; Bermudas (A. Ag.)

Mellita testudinata Klein.

Nat. Disp. Ech., 1734; A. Agass., Illust. Cat., No. VII, p. 141, 1872.

Maranhao (Agassiz, Thayer Exp.; (). А. Derty, 1870). Itaparıea and Camnavieiras, Prove of Rahia (Rathbun). Rio I)oce and Itabapuana, Pror of Espirito Sinto (IIartt and Copeland, Thayer Exp.). Vineyard sound-Florida; Texas; IVest Indies; Nexico; Cumana (A. Ag.)

Encope emarginata (Leske) Agass.

Mon. Scut., p. 47, 1841; Verrill, Trans. Conn. Acad., i, p. 370, 1868; A. Agass., Illust. Cat., No. VII, p. 126, 1872.

Maranhao (Agassiz, Thayer Exp.). Pernambuco and Maria Farinha (O. A. Derby, 1870; ( ieol. Comm.). Permambuen (Belval). Bay of Bahia, very aburiant on santy lottoms (IIart, '67; Rathbun). Rio Santo Antonio (Max, zu Neu Wied). Tictoria; Ilhas de Santa Anna (IIartt and Copeland, Thayer Exp.). IRio de Janeiro, very common on sandy shores, near entranee to Bay, ete. (Agaswiz, Thayer Exp); Rathbun). Desterro (F. Müller). S. Camolina-Florida; West Indies; Yucatan; Nicaragua; Cumana (A. Ag.).

\section{ASTERIOIDEA.}

Asterias Atlantica Verrill.

Trans. Conn. Acad., i, p. 368, 1868.

Abrolihos Recef's (IIartt, '6z). Only a single specimen of this species, the one collected by Prof. IIartt, hats been recorded from Brazil. Bermudas; Remedios, Cuba? (Verr.)

\section{Leptasterias Harttii, sp. nov.}

A very small star-fish, with six rays. Rays elevated, nearly or quite as high as broar, somewhat flattened below, but strongly and regularly arched above, and regularly tapering to rather sharply pointed tips. Disk small, its diameter equal to about one and onehalf times the wilth of the rays near lase. Radii as $1: 6$ nearly, the greater radius of the largest specimen examined being about $19^{\text {mum }}$.

Adambulacral spines rather slender-elavate toward base of ray, but tapering somewhat farther out, placed regularly two to a plate, those of the outer row slightly larger than the inner. Ventral spines 
very much broaler than the above, but not much longer, clavate in general form, with compressed tips, not arranged regularly in longitudinal rows, but in short, slightly ol,lique series of two, seldom three, spines. Between the ventral and atambulacral rows of spines the intervening space is very narrow, hut the ventral and lateral rows are widely separater. The lateral and dorsal spines are all of subequal size, very small and short, about one-half as long as the arlambulacral or even shorter, cylindrieal, or slightly tapering, and with truncate, rounded ends. First above the ventrals comes a single row of these spines, rather widely separated, and arranged one to a plate, seldom two, with sometimes a short lower row, of six or seven smaller spines, near the midclle of the arm. Above the first lateral rows of each sirle, we can distinguish in all five longitudinal series of spines, inclnding the median dorsal one. In these series the spines are not generally regularly placerl, but we can make ont a certain arrangement among them. The first series consists usually of two rows of alternating spines, distinct nearly or quite to the tip of arm. The second series, towarl the disk, is mate up of suceessive, irreguar or slightly enred, transwerse rows of four or five spines, with an intervening spine to conneret the sereral rows; farther out the series becomes resluced to a single, irregular, longitulinal row of spines. The median dorsal series is formen of similar transverse rows of about five spines each, arranged irregularly in the shape of at very broad $V$, with the angle tumed toward the disk; toward the tip there are only two or three spines to a group. Near the disk there are many additional spines seatered over the arms, more or less obscuring the above arangement. The spines of the disk are similar in character to those of the rays, and of the same size or slightly smaller; they are closely arranged but without order.

The major pedicellaria are very large and numerous, being scatterel over the entire surface of the rays and lisk. Where perfectly preserved, they are elongate triangular in ontline, with strongly curved base, and are about two-thirds as broad ats long; they often appear ovate in ontline. They vary in size, many being only onehalf or two-thirds as long as others. The larger ones equal or slightly exceed the lateral and dorsal spines in length, and are very much broader. Everywhere above the first lateral rows of spines, they are about uniformly distributerl, ranging most commonly along the edges of the plates. Between the ventral and lateral rows of spines, they are much more numerous, being especially abundant just above the bases of the rentral spines. They also occur, hit more 
rarely, between the rentral and adambulacral rows of spines. On the disk they are about as numerous as upon the dorsal side of the arms.

The madreporic plate is small, flattened, rather low down between the arms, and surromded by a row of spines; it has but few, rather simple convolutions. The openings between the plates, on the inner balf of the arm, are rather large; papulie placed singly. The above description was made from dried specimens.

This species may be readily distinguished by its very small, simple spines, and proportionately very large pedicellarie; the latter often much exceed the former in size.

Locality: About 30 miles east of Cape Negro, Brazil, lat. 2:3 $20^{\prime} \mathrm{S}$, depth 62 fathoms, gravelly bottom. Brought up on the cable by the telegraph steamer "Norseman."

\section{Echinaster echinophorus (Lam.) Perrier.}

Arch. de Zool. Expér., iv, No. 3, p. 364, 1875.

Echinaster (Othitia) crassispina Verrill, Trans. Conn. Acad., i, p. 368, 1868.

This species is apparently the most common one of the genus Echinuster on the Brazilian coast. Specimens collected at the Abrolhos Islands in 1876, agree perfectly with the types of $E$. crassispinu, from the same locality, as described by Prof. Verrill (loc. cit.). The same species also occurs in great abundance at many places in the Bay of Bahia, generally on rocky bottom (Rathbun); on the coast of the province of Peruambuco (Branner); and near the mouth of the Rio Parahyba do Norte (Br.). It undergoes considerable variation, at times approaching the next species enumerated in this list, and the study of a large series of specimens might serve to prove the identity of the two species. It is generally found in slight depths of water, and when living is of a very bright red color. Bahia and Rio de Janeiro (Perrier, in the Museum at Paris from Castelneau). It is extremely doubtful if this species oceurs at Rio de Janeiro.

West Indies (Lütken). North America; Yueatan; Central America (Perrier).

Echinaster sentus (Say) Lütken.

Vidensk. Meddel., p. 284, 1871.

From the Bay of Bahia, there were procured by the author, in 1876 , several specimens of Echimster, which it is impossible to distinguish from authentic specimens of $E$. sentus from Florida and the West Indies. This species does not, however, appear to be common at the former locality. A single specimen of this genus, collected at Per.

Trans. Conn. Acad., Vol. V. 
nambuco in 1870, by Mr. O. A. Derby, ant contained in the Museum of Yale College, approaches more closely to this than any other described species. Its greatest dianeter is about $120^{\text {mun }}$, and it has more slender and gradually tapering arms than typical specimens of $E$. sentus. 'The spines are slightly longer than usual in this species, and number about eighteen in each of the upper median rows from the center of the disk to the tip of the arm. At Rio Formoso, Pernambuco (Brammer) were found young inclividuals of this same variety, associated with more typical specimens of $E$. sentus. Florida; Hayti (Verrill). West Indies (Mus. Yale Coll.).

\section{Echinaster Braziliensis Müll. and Troseh.}

Syst. der Asterid., p. 22, 1842.

I have seen only a single specimen that conld be referred to this species, as originally described by Müller and Troschel; it was from Rio Formoso, Pernambuco (Brammer). Greatest diameter about $80^{\text {mm }}$, arms quite slemler, spines very small and arranged in about nine longitudinal rows, the upper median rows of each arm containing 25-30 spines, from center of disk to tip of arm.

Brazil (Mäll. and Trosch., in Mus. Berlin). Rio de Janeiro (I'errier, in Mus. P'aris, collected by Freycinet, 1822, Gandichand, 18:39, and Castelneau, 1844). This species was not found at Rio de Janeiro by the

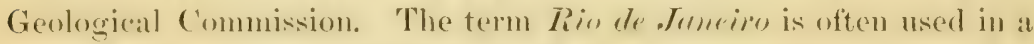
general way to designate Brazil, and it is mot improbable that the specimens in the Paris Museum came from some other part of the eoast.

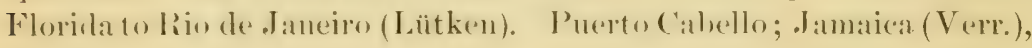

\section{Linckia Guildingii Gray.}

Ann. and Mag. Nat. Hist., vi, p. 285, 1840.

Linckia ornithopus (Lütken) Verrill, Trans. Conu. Acad, i, p. 367, 1868.

Rio Formoso, Pernambuco (Bramere). Maceelo, Mlagoas (Iiartt, '67). Mar (iramle, Bay of' Bahia (Rathbun). Abrolhos Reefs (IIartt, 'bל). So falr as known, this species is very rare on the Brazilian coast, only a few specimens having been eollected at each of the aloove localities. Bahia (Perrier, Mus. Paris). Vera C'ruz; (xumleloupe; Cape Verde Isls. (Perr.). St. Thomas (Ltk.). St. Vincent (Gray).

Pentagonaster semilunatus (Linck, 1733) Perrier.

Arch. de Zool. Expér., v, No. 1, p. 24, 1876.

Goniaster cuspidatus Gray, Ann. Nat. Hist., vi, p. 280, 1840.

Brazil (Perrier, Mus. Paris, from Castelneau). 
According to the generally accepted rules of nomenclature, the above name should give place to one of more modern date, and of such there is an abuudance in the long list of synonyny arranged by M. Perrier. As, however, he is the authority for the consolidation of several of the species included in that list, and also for the determination of the only specimens that appear to be recorted from Brazil, I prefer to retain here the old name of Linck, which he has revived. Indian Ocean (Müll. and Tr.). China; West C'oast of Africa, at Gorée, S'énégal; Bissagos and Cape Verde Isls. (Perrier). Off Charleston, S. C. (Goniaster Americanus Verrill).

\section{Oreaster gigas (Linn.) Lütken.}

Vidensk. Meddel., 1859, p. 64; Verrill, Trans. Conn. Acad., i, p. 367, 1868.

City of Pernambuco, and also at several places in the same province to the north of the city, abundant (Geol. Comm.). Bay of Bahia, abundant nearly everywhere, on sandy bottom, from lowwater mark to two fathoms and deeper; Abrolhos Islands; Caravellas Barra (Rathbun). Abrolhos Reef's (IIartt,'67). Bahia (Perrier, Mus. Paris). St. Thomas (Ltk.). West Indies; Barbadoes; st. Vincent (Gray). Hayti; Florida (Verrill).

Asterina marginata (Hupé) Perrier.

Arch. de Zool. Expér., v, No. 2, p. 220, 1876.

Brazil; Rio de Janeiro (Perrier, Mus. Paris). Brazil (Müll. and Trosch., Mus. Viema). Specimens apparently of this species were collected in the Bay of lio de Janeiro, by Mr. Branuer. S'négal (Perrier).

\section{Luidia Senegalensis (Lam.) Müll. and Trosch.}

Syst. der Asterid., p. 78, 1842.

Luidia Marcgravii Steenstrup, in Lütken, Vidensk. Meddel., p. 43, 1859.

Rio Formoso, Pernambuco, very abundant and often of large size (Brammer). One specimen, collected by Mr. Brauner, had a greatest diameter of more than $360^{\text {min }}$; diameter of disk, $51^{\text {mim }}$. All the specimens observed had nine arms. Pernanbuco (Derby, '7o, in Mus. Yale Coll.). Brazil (Perrier, Mus. Paris). Sénégal; Guadeloupe (Perrier). Jamaica (Browne). 
Luidia clathrata (Say) Lütken.

Vidensk. Meddel., 1859, p. 37.

Rio de Janeiro (Perrier, Mus. Paris). A young specimen, probably of this species, was collected in Botafogro Bay, Rio de Janeiro; and two larger specimens, agreeing perfectly with the small one from Rio, were obtaned in the Bay of Bahia (Rathbun). N. Carolina-Florida; West Indies (Perr, and Verrill).

Astropecten Braziliensis Müll. and Trosch.

Syst. der Asterid., p. 68, 1842.

Bay of Rio de Janeiro, common (Rathbun). Brazil (Perrier, Mus. Paris; Müll. and Trosch., Mus. Vienna).

\section{Pteraster Danæ Verrill.}

Proc. Bost. Soc. Nat. Hist., xii, p. 386, 1869.

Rio de Janeiro? (J. D. Dana, U. S. Exploring Exp.) It has since been dredged on the east coast of Patagonia (Lütkeu), and it is possible that the Exploring Expedition specimen also came from that region.

\section{OPHIUROIDEA.}

Ophiura cinerea (Müll. and Tr.) Lyman.

Illust. Catal. Mus. Comp. Zoology, No. I, p. 27, 1865 ; Verrill, Trans. Conn. Acad., i, p. $367,1868$.

This Ophiman is one of the commonest on the northern and central coasts of Brazil; but it has not been recorded from south of the Abrolhos Islands. It is generally found between high and low water marks, under stones in the shallow pools of the rocky shores and coral reefis, in which situations it often occurs in great abundance. The largest specimens obtained were from Fernando de Noronha. One of these afforled the following measurements; diameter of disk, $37^{\text {mm }}$, length of arm, $210^{\mathrm{mm}}$.

Fernando de Noronha; Parahyba do Norte (Branner). Plataforma, Mar Grande, and throughout the Bay of Bahia (Rathbun). Abrolhos Islands (Hartt, '67). Mr. Lyman refers doubtfully to this species an Ophiuran obtained by the Hassler Expedition in lat. $11^{\circ}$ $39^{\prime} \mathrm{S}$., long. $37^{\circ} 20^{\prime} \mathrm{W}$., depth 75 fathoms. Florida; West Indies; Gulf of Mexico (Lym.). Aspinwall (Verrill). 


\section{Ophiura appressa Say.}

Jour. Phil. Acad., v, p. 151, 1825 ; Lyman, Illust. Cat., No. I, p. 34, 1865.

Parahyba do Norte; Rio Formoso, Pernambuco (Bramer). Plataforma, Bay of Bahia (Rathbun). Generally foumd associated with O. cinerect. Bahia (Lütien). Dbout the same general distribution as $O$. cinerea.

Ophiura brevispina Say.

Loc. cit., v, p. 149, 1825; Lyman, Illust. Cat., No. I, p. 18, 1865.

Brazil (Ljungman). Florida; Bahamas ; St. Thomas (Lyman).

Ophiura Januarii (Lütken) Lyman.

Illust. Cat., No. I, p. 25, 1865.

Rio de Janeiro (Lütken, collected hy Prof. Iñöyer). Cotinguiba, Prov. of Rergipe (Lïken, collected by Capt. Hygom). Southern Brazil (Ljung.).

Ophiolepis paucispina (Say) Müll. and Trosch.

Syst. Asterid., p. 90, 184² ; Lyman, Illust. Cat., No. I, p. 55, 1865 ; Verrill, Trans. Conn. Acad., i, p. 367, 1868.

Abrolhos Islands (IIartt, '67). One small Ophiuran, dredged in 3-4 fathoms, near the Island of Paqueta, Baty of Rio de Janeiro, appeared to be the young of this species (Rathbun). Florida; West Indies (Lyman).

Ophioceramis albida (Ljung.) Lyman.

Illust. Cat., No. VIII, part II, p. 10, 1875 .

Rio de Janciro IIabor (Hassler Exp.). Atlantic, near Rio de Janeiro (Ljungman, collected by Irimberg'). Oft' the Rio de la Plata, 19-4t fathoms; East Irgentina, 34 fathoms; Barbadoes, 100 fathoms (H. E.).

Ophioceramis Januarii (Lütken) Lyman.

Illust. Cat., No. I, p. 62, 1865 .

Rio de Janeiro (Lütken, collected by Prof. Írüyer). Off̉ Bahia, 40 fathoms; Cape Frio, 35 fathoms (H. E.). Barbadoes, 100 fathoms; East Patagonia (H. E.). 
Ophionereis reticulata (Say) Lütken.

Addit. ad Hist. Oph., p. 110, 1859 ; Lyman, Illust. Cat., No. I, p. 141, 1865; Verrill, Trans. Conn. Acad., i, p. 366, 1868.

Plataformat and Mar Gramde, Bay of Bahia, that rocky shores, nuder stones, moderately abundant (Jiathbun). Abrolhos Islands (Ilart, "67; Rathbun). Rio de Janeiro Irarbor" off Cape Frio (H. E.). Northeru Brazil (Tjungman). Florida; West Indies; Bay of Cumana; Bermudas (Lyman).

Ophiocoma echinata (Lam.) Agass.

Prod. Mém. Soc. Scien. Nat. de Neuchatel, i, 1835 ; Lyman, Illust. Cat., No. I, p. $81,1865$.

Several specimens of this species, in fine conclition, were brought from Parahyba do Norte, hy Mr. Bramer in 1876. They were oltainerl from shallow water, near the shore. A medium size specimen measured : liameter of tisk, 26.5"m ; length of am, $84^{m m}$. Florilar; West Inlies; Aspinmall; bay of C'umana (Lyman).

\section{Ophiocoma Riisei Lütken.}

Vidensk. Meddelelser, Jan., 1856, p. 14; Lyman, Illust. Cat., No. i, p. 76, 1865.

One harge specimen of this speecies was obtained by Mr. Branner in 1876, from the shore of the Island of Fermando de Noronha. It

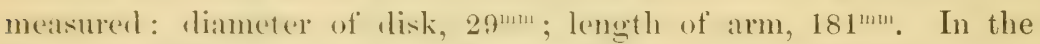
characters of its several parts it agreed quite (rosely with the descrip)tion of Mr. Lyman (loce cit.), the differences noted being such as would naturally arise timm its increased gowth. Floricla; West Indies; Bay of Cumana (Lyman).

\section{Ophiopsila Riisei Lütken.}

Addit. ad Hist. Oph., p. 136, 1859; Lyman, Illust. Cat., No. I, p. 150, 1865.

Northern Brazil (Ljungman). Florida (Lymau). Wrest Indies (Ljung.)

\section{Ophiothrix violacea Nüll, and Trosch.}

Syst. Asterid., p. 115, 1842 ; Lyman, Illust. Cat., No. I, p. 164, 1865 ; Verrill, Trans. Conn. Acad., i, p. 366, 1868.

This is onte of the most wide-spreat of the Brazilian Ophimrans, haring lexen recorded from I'arahyba rlo Norte in the north, to Rio de Jameiro in the south, and from the littoral zone to a depth of at least 35 fathoms. In the Bay of Bahia it is particularly abundant, 
being more common there than any other species. It mudergoes considerable variation as regards shates of coloration, but is otherwise quite constant in its characters.

Parahyba do Norte; Rio Formoso, Pernambuco; rery abundant. (Bramner). Plataforma, Mar Grande, Malpele, and nearly every where along the shores of the Bay of Bahia; also dredged in about 4 fathoms in front of the (ity of Bahia (Rathbun). Abrolhos Islamls, abundant (Hartt, '67; Rathluun). Near Bahia; lat. $11^{\circ}+9^{\prime} \mathrm{s}$., long. $37^{\circ} 27^{\prime}$ W. G. ; off Cape Frio, 35 fathoms; Rio de Janciro IIarbor, (H. E.). Rio de Janeiro (Lütken, coll. by Prof. Kröyer ; Müll. and Troseh., in the Huseum at Viemnil). Southern Brazil (Ljungman). Florida, shore to 50 fathoms; West Inclies; Yroatan (Lym.). Aspinwall ; Barbadoes (H. E.).

\section{Ophiothrix Suensonii Lütken.}

Vidensk. Meddel., Jan., 1856, p. 16 ; Lyman, Illust. Cat., No. I, p. 157, 1865.

Lat. $22^{\circ} \mathrm{S}$, long. $40^{\circ} \mathrm{W}$. G., sandy bottom, depth not recorded; obtained by the Brazilian cable rejair steamer "Norseman," 1sz6, (irlentified by Mr. Theo. Lyman). W'st Indies; Carthagena, New Granada (Lyman). Barbadoes, 100 fathoms (H. E.)

\section{Ophiactis Krebsii Lütken.}

Addit. ad Hist. Oph., p. 126, 1859; Lyman, Illust. Cat., No. I, p. 111, 1865; Verrill, Trans. Conn. Acad., i, p. 366, 1868.

Plataforma, Bay of Bahia, only a few specimens obtaned (Rathbun). Alorolhos Islambls (IIartt, '67). Near Iskamel of I'aqueta, Bay

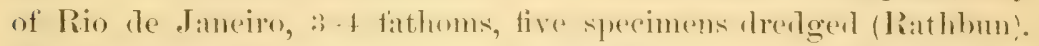
The majority of the specimens whtained hat six arms. S. Carolinat -Florida; Bahamas; St. Thomas (Lyman).

\section{Ophiactis Mülleri Lütken.}

Addit. ad Hist. Oph., p. 127, 1859; Lyman, Illust. Cat., No. I, p. 109, 1865.

Off the Abrolhos Islamds, 30 fathoms (II. E.). Florida; West Indies (Lyman).

Hemipholis cordifera (Bosc) Lyman.

Illust. Cat., No. I, p. 137, 1865.

Southern Brazil (Ljungman). S. Carolina (Lyman). 


\section{Amphiura Kinbergi Ljung.}

Vestindiska och Atlantiska Ophiurider, p. 643, 1871.

Southern Brazil (Ljungman).

Amphiura flexuosa Ljung.

Oph. Viventia, p. 319, 1866.

Southern Brazil (Ljungman, coll. by Kinberg). Barbatoes, 100 fathoms? (H. E.). Key Biscayne, Fla. ? (Lyman).

\section{Amphiura Stimpsonii Lütken.}

Addit. ad Hist. Oph., p. 116, 1859.

Off' ('ape Frio, 35 fathoms (II. E.). West Inties (Lyman).

Amphiura complanata Ljung.

Oph. Viventia, p. 319, 1866.

Atlantic Ocean, lat. $22^{\prime} 30^{\prime} \mathrm{S}$.; long. $40^{\circ} 55^{\prime} \mathrm{W}$. (Ljungman, coll. by Kinberg). Also from northern Brazil (Ljung.)

Amphiura crassipes Ljung.

Oph. Viventia, p. 319, 1866.

Atlantic ocean, lat. 22: $30^{\prime} \mathrm{s}$., long. $40^{\circ} 55^{\prime} \mathrm{W}$. (Ljumgman, coll. by Kinberge). Mr. 'Theor. Iyman has referred doubtfully to this species a single specimen of Ophintan, obtained in 1876 by the steamer "Norseman," abont twenty-five miles sonth of the entrance to the bay of lio de Ianciro, in 45 fathoms. The specimen was too much mutilated to permit of an aceurate determination.

Amphiura tenera Lütken.

Addit. ad Hist. Oph., p. 124, 1859 ; Lyman, Illust. Cat., No. I, p. 123, 1865.

Off Cape Frio, 35 fathoms (II. E.). S. Carolina; West Indies (Lyman).

Amphiura duplicata Lym.

Illust. Cat., No. VIII, part II, p. 19, 1875.

Brazil? (H. E.). Barbadoes, 100 fathoms (H. E.).

Amphiura planispina E. v. Martens.

Monatsbericht der Kon. Akad. Berlin, p. 347, 1867.

Rio de Janeiro. 
Amphipholis Riisei (Lütken) Ljung.

Opl. Viventia, p. 313, 1866.

Southern Brazil (Tjungman). WVest Indies (Ljungmam).

Amphipholis Januarii Ljung.

Om nagra nya arter af Ophiurider, p. 165, 1866.

Bay of Rio de Janeiro (Ljungman, coll. Kinberg).

Amphipholis subtilis Ljung.

Oph. Viventia, p. 314, 1866.

Atlantic, near Rio de Janeiro (Ljungman, coll. Lovén).

Amphipholis limbata (Grube) Ljung.

Oph. Viventia,-p. 314, 1866.

Rio de Janeiro (Lyman). Coast of Brazil (Ljungman).

Ophiocnida scabriuscula (Lütken) Lyman.

Illust. Cat., No. I, p. 135, 1865.

Plataforma, Bay of Bahia, near low-water mark (Rathbun,identified by Mr. Theo. Lyman.) Florida; West Indies (Lyman).

\section{Ophiocnida Loveni Lyman.}

Bull. Mus. Comp. Zool., i, No. 10, p. 337, 1869.

Ophiophragmus Lovéni Ljung., Om nagra nya arter af Oph., p. 165, 1866.

Amphipholis Loitni Ljung., Testindiska och Atlantiska Ophiurider, p. 648, 1871.

Bay of Rio de Janeiro (Ljungman, coll. by Kinberg). Off the Island of Paqueta, Bay of Rio de Janeiro, $3-1$ fathoms, muddy bottom (Rathbun,-identified by Mr. Theo. Lyman).

Ophiostigma isacanthum (Say) Lyman.

Ilust. Cat., No. I, p. 103, 1865.

Off Cape Frio, 35 fathoms (H. E.). Florida,-63 fathoms; St. Thomas; St. John (Lyman).

Ophiomyxa flaccida (Say) Lütken.

Addit. ad Hist. Oph., p. 138, 1859; Lyman, Illust. Cat., No. I, p. 178, 1865; Verrill, Trans. Conn. Acad., vol. i, p. 366, 1868.

Abrolhos Islands (Hartt, '67). Near Bahia (II. E.). Florida,-50 fathoms; West Indies (Lyman).

Trans. CONN. ACAD., VOL. V. 


\section{CRINOIDEA.}

\section{Antedon carinatus?}

Alecto carinata Leach.

Comatula carinata Lamarck, Inim. sans Verteb., 2d ed., iii, p. 210, 1840.

Antedon Inülenii Verrill (non Bölsche), Trans. Conn. Acad., i. p. :365, 1868 (with?).

Mr. L. F. de Pourtales, in a recent publication, ${ }^{*}$ refers to Commtulu cerinatu Lam., with query, a species of Anteclon which he states to be common on the Brazilian coast. He does not, however, give the exact localities from which the specimens he has examined were olbtainerl. Only two species of Antedon were collected by the members of the Greological Commision. One of these is a small species, with more than ten arms, to be describerl further on ; the other is tenarmed, and from comparisons I have been able to make is evidently identical with the form mentioned by Mr. Pourtales. It was found in abumelance at Rio Formoso, Pernambuco, at many localities in the Bay of Bahia, and at the Abrolhos Islands; but probably ranges along the entire coast, at least as far sonth as Rio de Jameiro. It generally oceurs in holes and erevices of the rocky shores, and of millepores and other corals, clinging tightly by means of its cirri, but eompletely exposing its arms. I single, much mutilated speejmen was collected at the Abrolhos Islanks, by Prof. Hartt in 186 , and referred doubthilly to Intedon Dübenii Bölsche, by Prof. Verrill. Another specimen contained in the Peabody Museum of Yale ('ollegere, wats received from I)r. C F. Lütken, labeled Antedon Broziliensis Läte, lio de .Taneiro. This is apparently the same as the form now mmler discussion, and it approaches in many of its characters more closely the A. cerinatus of the Mauritius and Zanzibar, than do the specimens from northern Brazil.

The P'eabody Museum possesses several specimens of intedon from Zatuzibar, which, although I fomi them undetermined, agree so closely with the original hescriptions of 1 . arinatus, as to leave little loubt of their identity. 'The Brazilian forms that I have been able to study differ from the Zamzibar specimens about as follows:The 1. Breziliensis, above mentionerl, has the dorsal side of the arms rather more strongly carinate, the tuberele projecting from the median outer edge of each joint being ustually very strongly marked, and often reaching inwart one-half to two-thirk the length of the joint, as a very prominent, slightly elongate, sub-angular ridge, with a minutely spinose surface. One or two joints alternate between the

* Bull. Mrus. Comp. Zoology, Cambridge, v, No. 9, p. 214, 1878. 
sucessive syzygia. In the characters of the cirri and the centrodorsal piece there are no appreciable differences.

The specimens from Bahia and Pernambuco, on the contrary, differ mostly with regard to the centro-dorsal piece and the cirri. The former is usually proportionately broaler and flatter, but is extremely variable. The cirri are, as a rule, proportionally longer and fewer in number; they are placed in about two irregular rows, or in one crowded row, and range in number from about fifteen to thirty, on medium-sized specimens. 'They are composed of from nineteen to twenty-two joints each. The total sprear of the largest perfect specimen observed was a little over twenty-five centimeters. The color varies from a light yellowish brown to a deep violet, with many intermediate shades, specimens being usually banded with lighter and darker colorings, and seldom of uniform tint.

The study of a large series of specimens would probably serve to unite the Brazilian with the East African species beyond all doubt.

\section{Antedon meridionalis (A. Ag.) Verrill.}

Proc. Bost. Soc. Nat. Hist., vol. x, p. 339, 1866 ; Pourtales, Bull. MIus. C'omp. Zool., i, No. 11, p. 355, 1869 ; Ibid., v, No. 9, p. 214, 1878.

Charleston, S. Carolina, to C'ape Frio, Brazil (Pourtales, Mus. Comp. Zool.)

\section{Antedon Dübenii Bölsche.}

Archiv. für Naturgeschichte, 1866, p. 92.

Rio de Janeiro (Bölsche).

\section{Antedon, sp.}

A small species of Antedon, having between ten and twenty arms, was collected by Mr. Bramner, in great abundance at some locality not definitely recorded, either on the coast of Pernambuco, or of Parahyba do Norte. I have not been able to identify it with any deseribed species that has come under my notice, although it may not be new.

It is rather a delicate species, with slenter arms and cirri, the former at times presenting only one division of the second order resulting in the formation of eleven arms. 'There may, however, be any number of arms, up to at least twenty. It has a total spread of only about $9^{\text {cu }}$, the centro-dorsal piece, measuring $2^{\text {mm }}$ in diameter, being flat and destitute of cirri on top, but sometimes still preserving 
there traces of their points of attachment. Around the edge of the piece is a single row of twelve to sixteen cirri, each composed of eleven to twelve simple joints, in addition to the large, incurved, sharply-pointed terminal spine. First joint very short; second as long as broad; third to sixth or seventh longer than broad, somewhat constricted toward the centre, or enlarged at the ends, so as to produce a series of swellings along this part of each cirrus; the remaining joints, to the tip, decrease successively in size, and are slightly compressed laterally, the last three bearing each a minute, sharp tubercle at or near the upper distal end.

First radial slightly exposed; axials low, pentagonal; usually three brachials between first and second axials, and one brachial between sceond and third axials, when the latter occurs. At base of arm the joints are simple; but shortly after the last division they become rather long, and well-separated, with an oblique distal edge, which is thin and slightly raised so as to appear imbricating; this edge terminates in a row of minute, sharp tubercles. The first pimule starts from the second joint after the first division; after the second division, there is a pinnule to each joint on alternate sides, with seldom an intervening joint. The first pimnles are very long and slender, their length being equal to about the diameter of the oral surface of the disk, or slightly greater. They are composed of rather elongated joints, those toward the base having their distal ends, on two sides, thin, slightly devated and minutely spinose. The last seven to ten -not incluling the three terminal ones-bear each a very large, irregular tubercle, which is nearly as long as the joint itself. In alcoholic specimens these pinmules curve gracefully over and lic entangled together upon the oral side of the disk, appearing not unlike the young, unfolding fromls of a ferm. The second pinnules are similar in strueture to the first, but shorter. The others, to tips of the arms, are of subequal size throughout, and from one-third to one-half the length of the first; they are rather broaler at the base, and each of the three terminal joints composing them is marked with a minute, sharp tubercle.

Oral surface very minutely graunlose; mouth eccentric; anus nearly central, raised on an elevated, conical prominence. 



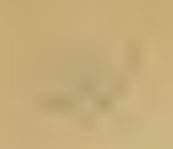






1 





